\title{
Histopathological Study of the Alternaria solani Infection Process in Potato Cultivars with Different Levels of Early Blight Resistance
}

\author{
M. A. Dita ${ }^{1,2}$, S. H. Brommonschenkel ${ }^{2}$, K. Matsuoka ${ }^{2}$ and E. S. G. Mizubuti ${ }^{2}$ \\ Authors' addresses: ${ }^{1}$ Embrapa Mandioca e Fruticultura Tropical, PO Box 007, 44380-000, Cruz das Almas, Bahia, Brazil; \\ ${ }^{2}$ Departamento de Fitopatologia, Universidade Federal de Viçosa, 36570-000 Viçosa, Minas Gerais, Brazil (correspondence \\ to M. A. Dita. E-mail: miguel@cnpmf.embrapa.br)
}

Received October 17, 2006; accepted February 7, 2007

Keywords: age-related disease resistance, histopathology, quantitative resistance, hypersensitive reaction, Solanum tuberosum

\begin{abstract}
Histopathological analyses of the infection process of Alternaria solani were accomplished in three potato cultivars with different levels of early blight resistance. Leaflets of Aracy (resistant), Delta (moderately resistant) and Bintje (susceptible) cultivars were inoculated at the beginning of the flowering stage. In order to study the effect of leaf age, leaf samples were collected separately, in the lower, middle and upper third of the plants. Conidia germination, appressoria formation, penetration and number of penetration sites exhibiting hypersensitive response (HR) were qualitatively and quantitatively assessed at 6, 12, 24, 48 and $72 \mathrm{~h}$ after inoculation. Penetration occurred most frequently through the junctions of the epidermal cells. Penetrations through stomata were rarely observed. There was no association between the events and the resistance levels, except for the number of penetration sites showing HR that was highest in Aracy, intermediate in Delta and lowest in Bintje. Similarly, the number of sites with HR was the only event associated with the leaf age. Regardless of cultivar resistance levels, the number of the penetration sites with HR was higher in leaves in the upper part of the plant. These results suggest that HR may be one of the mechanisms associated with age-related and genetic resistance to early blight in potato.
\end{abstract}

\section{Introduction}

Potato early blight (EB), caused by the mitosporic fungus Alternaria solani Sor., is an important foliar disease that occurs in potato-growing regions worldwide (Christ, 1991; Rotem, 1994; Van der Waals et al., 2003). The disease may cause rapid plant defoliation, which may result in reduction of the vegetative cycle and yield losses. In Brazil, during the rainy season, EB is the most limiting disease for potato production (Reifschneider et al., 1984) and frequent fungicide sprays are commonly used to prevent crop losses. Cultivar resistance is the most promising strategy to manage EB, but most commercially-grown potato cultivars in Brazil are susceptible to EB.

It has been repeatedly observed that resistance to EB is age-related: older leaves are more susceptible and susceptibility increases as plants grow older (Douglas and Pavek, 1972; Pelletier and Fry, 1989). In resistant cultivars as well as in young leaves, the incubation period is long and there are small numbers of lesions, suggesting that resistance mechanisms may act during the early stages of the infection process (Dita et al., 2006). However, to date, cytological and molecular studies to address the mechanisms involved in the resistance have not been conducted in the potato $A$. solani pathosystem.

Histopathological studies of the host-pathogen interaction can help identify events that occur during the pathogenesis, and ultimately lead to a better understanding of resistance mechanisms (Sillero and Rubiales, 2002; Vleeshouwers et al., 2000; Xi et al., 2000). Events associated with the pathogenesis of Alternaria spp. in different host species such as conidia germination, appressoria formation and penetration have been studied (Allen et al., 1983; Aveling et al., 1994; McRoberts and Lennard, 1996; Vandyke and Trigiano, 1987). However, most of these studies described the infection processes in susceptible cultivars. Histopathological studies comparing events in resistant and susceptible cultivars and in tissues with different ages are scarce. In studies, carried out with tomato, formation of few appressoria was associated with EB resistance (Araújo and Matsuoka, 2004) whereas the hypersensitive response (HR) to be related to non-host resistance to Alternaria alternata f.sp. lycopersici (Brandwagt et al., 2001). In the potato- $A$. solani interaction, however, no histopathological studies comparing genotypes with different levels of resistance to EB and tissues with different ages have been conducted. 
Furthermore, there is no detailed description of the infection process in this pathosystem.

We have recently reported the effects of the leaf position on components of resistance to EB in potato cultivars with different levels of resistance (Dita et al., 2006). A step further would be to identify the cytological mechanisms associated with the resistance and to determine the time when they are deployed. Therefore, the purpose of this study was to accomplish a histopathological analysis of the infection process in three potato cultivars with distinct levels of EB resistance, aiming at describing the infection process as well as at identifying possible structural mechanisms related to the resistance levels of the cultivars including the age-related relationship.

\section{Materials and Methods}

Plant growth and inoculum production

Three potato cultivars with different levels of EB resistance were selected: 'Aracy' was used as resistant, 'Delta' as moderately resistant and 'Bintje' as susceptible cultivar. Tubers of about $50 \mathrm{~g}$ were planted in 8 1-plastic pots filled with soil, sand and compost mixture in a $3: 1: 1(\mathrm{v} / \mathrm{v})$ ratio. All experiments were performed with a monosporic culture of $A$. solani (isolate ASA02), obtained from a naturally infected potato plant. Isolate was grown on Potato Dextrose Agar medium in Petri dishes kept on an incubator at $24^{\circ} \mathrm{C}$, in the dark, until colonies reached $8 \mathrm{~cm}$ in diameter. Inoculum suspension was produced as described elsewhere (Dita et al., 2006).

\section{Inoculation and evaluation of the infection process}

Before inoculation, three sections: lower, middle and upper were properly labelled in each plant. The term plant position or leaf position, used along in the text, corresponds to these three sections. Although leaf age was not precisely determined, we assumed that leaves collected from lower, middle and upper sections, ranged from older to younger physiological stages, respectively.

Three consecutive series of experiments were performed. In each experiment 15 plants per cultivar were used. Ten plants were inoculated and five were used as control (not inoculated). Seven of the 10 inoculated plants were used for collecting samples. The remaining plants (three) were used to assess inoculation efficiency. A $10 \mu$ l-drop of a $10^{4}$ conidia per $\mathrm{ml}$ suspension supplemented with gelatin $\left(\right.$ Sigma $\left.^{\circledR} 1 \% \mathrm{w} / \mathrm{v}\right)$ was placed in an area of about $4.0 \mathrm{~cm}^{2}$ previously marked in the adaxial surface of the leaflets. At least 30 leaflets were inoculated in each plant section. Aliquots $(10 \mu \mathrm{l})$ of gelatin without conidia were drop-placed on the leaflets of the non-inoculated control plants. After inoculation, plants were covered with polyethylene bags which had its interior part wetted with distilled water to form individual humid chamber and kept at $25^{\circ} \mathrm{C}$ for $24 \mathrm{~h}$. After this incubation time, the plants were transferred to the greenhouse and the bags were removed. Three inoculated leaflets were randomly collected at 6, 12, 24, 36,48 and $72 \mathrm{~h}$ after inoculation from the lower, middle and upper third sections of each plant. Leaflet sections of about $0.5 \mathrm{~cm}^{2}(1.0 \mathrm{~cm} \times 0.5 \mathrm{~cm})$ were cut in the area previously marked on the leaflets and discolored in chloral-hydrated solution $(2.5 \mathrm{~g} / \mathrm{ml})$. After 5 days, discolored leaflet sections were placed in microscopic slides and stained with trypan blue $(0.05 \%)$. Three slides with four independent trypan-blue stained leaflet sections per treatment were examined by differential interference contrast microscopy (Olympus Vanox Microscope Platform, Olympus Japan Co., Ltd). The infection process was examined in all treatments and the following events were quantified:

Germination: Germinated conidia were considered as those in which germination tubes were present, regardless of either length or number of germ tubes per spore.

Appressoria: All globular structures with larger diameter than that of the germination tubes or hypha of origin were considered as appressoria and counted. No distinction between lateral and terminal appressoria was made.

Penetration: Penetration sites were recorded when fungal structures were observed beneath the epidermal cells. This event was recorded independently of the penetration place and host reaction.

Penetration sites exhibiting HR: This event was recorded when host epidermal cells had thickened cell wall, extensive cytoplasmic granulation and high levels of autofluorescence in response to pathogen penetration.

\section{Scanning electron microscopy assay}

In order to obtain a more accurate understanding of pre-penetration events of the infection process, scanning electron microscopy analyses were performed with infected tissues of 'Bintje' collected $24 \mathrm{~h}$ after inoculation. Plants were grown as indicated above and preand postinoculation conditions were also similar. Inoculation was accomplished by atomization of a $10^{6}$ conidia per $\mathrm{ml}$ suspension onto all leaflets. This high inoculum concentration was used in order to increase the probability of finding sites with infection events. Leaflet sections of about $16 \mathrm{~mm}^{2}(4 \mathrm{~mm} \times 4 \mathrm{~mm})$ were cut and subjected to prefixation in glutaraldehyde $(3 \%$, buffered with sodium cacodilate $\mathrm{pH} 7,0.05 \mathrm{M})$ for $2 \mathrm{~h}$ at room temperature. Sections were then washed six times in sodium cacodilate and fixation was carried out in osmium tetroxide $\left(\mathrm{OsO}_{4} 1 \%\right)$ for $4 \mathrm{~h}$, at $4^{\circ} \mathrm{C}$. Leaflet sections were washed six times with sodium cacodilate buffer and dehydrated in alcoholic series (30, 50, 70, 80, 95 and $100 \%$ ). After dehydration, leaflet sections were dried to the critical point using a 'Critical Point Dryer' (Balzers, model CPD020, BAL-TEC AG, Switzerland) then placed in a metal support and covered with gold by cathodic pulverization in 'Sputter Coater' coupled to a 'Freezing Drying Unit' (Balzers, FDU010, BAL-TEC AG, Switzerland). Samples were examined with a JEOL scanning electronic microscope (JSM-T2000, JEOL, Peabody, MA, USA) operating to $10 \mathrm{kV}$. 


\section{Statistical analysis}

Previous analyses with samples collected at different time-points revealed that sampling at $36 \mathrm{~h}$ after inoculation allowed the best assessment of the infection events. Furthermore, there was no interaction between time-points and cultivars, thus the data from $36 \mathrm{~h}$ were used for the statistical analyses. Data from samples taken $36 \mathrm{~h}$ after inoculation from the repeated experiments were combined and subjected to analysis of variance. Germination of conidia was analyzed by comparing the means of germinated conidia per tissuearea $\left(2 \mathrm{~cm}^{2}\right)$ per treatment. The ratio (proportion) of appressoria per germinated conidia was calculated and analyzed. The number of penetrations per appressoria was estimated, as well as, the number of sites with HR relative to the number of penetration sites.

Because there was no significant interaction between resistance levels and plant sections, the effect of leaf position upon all pathogenesis events was analyzed using the data from each plant section (lower, middle and upper) pooled from the three cultivars. Thus, in each event the data from lower section of the plants of all cultivars were combined and compared with the data from the middle and upper plant sections. Mean values were compared using the Fisher $\operatorname{LSD}(\alpha=0.05)$ test. All analyses were accomplished using the Statistical Analysis System version 8.0 (SAS Institute Inc., Cary, NC, USA).

\section{Results}

Infection process of $\boldsymbol{A}$. solani in potato

For all cultivars, the first germinated conidia of $A$. solani were observed at $6 \mathrm{~h}$ after inoculation, increased at $12 \mathrm{~h}$, reaching the maximum at $36 \mathrm{~h}$ after inoculation. All conidia formed at least one germ tube, but on average each conidium formed 3.21 ( \pm s.d. 0.093) germ tubes that grew not oriented over the leaf surface. Germ tubes were not necessarily oriented towards stomata and often grew over them without forming appressorium (Fig. 1a). Germ tubes frequently branched and extended over various epidermal cells until forming appressorium and penetrating, predominately at the cell junctions. Conidia with short germ tubes, with an appressorium, also resulted in penetration (Fig. 1b). Appressorium formation increased significantly at $24 \mathrm{~h}$ after inoculation. At this time, appressoria were characterized by the hyaline dilations, prominent at the end of the germ tubes (Fig. 1c) or sidelong the hypha (Fig. 1d). Some non-penetrating appressoria originated new germ tubes, from which new appressoria could be differentiated and penetrate, or form a hyphae network. Most appressoria were formed at the cell wall junctions of the epidermal cells (Fig. 2a, b). On the appressorium surface, germ tubes and hypha, an extracellular substance was frequently observed (Fig. 2).

Penetration of tissues by $A$. solani began $24 \mathrm{~h}$ after inoculation increasing at $36 \mathrm{~h}$ and apparently only occurred after the formation of appressoria. The pathogen penetrated the leaf surface directly through the epidermis, usually at the site of cell wall junctions
(Figs 1d, 2a and 3c). Penetrations through the stomata were rarely observed. Once inside the tissue, the hyphae became thickened and abundant internal mycelium was formed (Fig. 1e). The internal mycelium branched and colonized the tissues (Fig. 1f). Tissue necrosis followed pathogen colonization and at $48 \mathrm{~h}$ after inoculation, macroscopic lesions in the discolored tissues were observed. The necrosis caused by the pathogen colonization prevented assessments in samples collected $72 \mathrm{~h}$ after inoculation.

Regardless of the penetration mode, host cell wall morphology at the point of infection was visibly modified in some cells (Fig. 3). These modifications were characterized by aggregated cytoplasm with abundant granulations and apparent cell wall thickening (Fig. 3e and $\mathrm{f}$ ). These cells when observed under fluorescence microscopy presented high levels of autofluorescence (data not shown). This type of reaction which was observed with higher frequency in penetration sites near the stomatal complex was considered as HR (Araújo and Matsuoka, 2004; Vleeshouwers et al., 2000). The pathogen was visibly restricted in the infection sites with HR. However, in the susceptible genotype, successful colonization was occasionally observed despite HR. Similar to pathogen penetration, cells with HR began to be observed at $24 \mathrm{~h}$ after inoculation and reached the maximum number at $36 \mathrm{~h}$ after inoculation.

\section{Quantification of the infection process events Germination}

Germinated conidia of $A$. solani were observed in all cultivars, regardless of resistance levels. The highest numbers of germinated conidia occurred on the susceptible cultivar Bintje, in all plant sections. Germination rates on 'Bintje' differed from Delta in the lower and the upper and from 'Aracy' in the middle and the upper plant sections, respectively (Table 1). There was no relationship between the number of germinated conidia and leaf position (Table 2).

\section{Appressoria}

There was no consistent association of number of appressoria formed by germinated conidia (appressoria/germinated conidia) and cultivar resistance level (Table 1). The lowest values were recorded in the susceptible cultivar Bintje. This event was not influenced by the leaf position (Table 2).

\section{Penetration}

In all three cultivars, penetration of $A$. solani occurred predominantly by direct mode and there was no association of this event and resistance level (Table 1). In addition, there was no effect of leaf position on the number of penetration sites (Table 2).

\section{Penetration sites with $H R$}

Penetrations sites exhibiting HR were observed in all cultivars. In the three plant sections, highest numbers of penetration sites with $\mathrm{HR}$ were recorded in the 

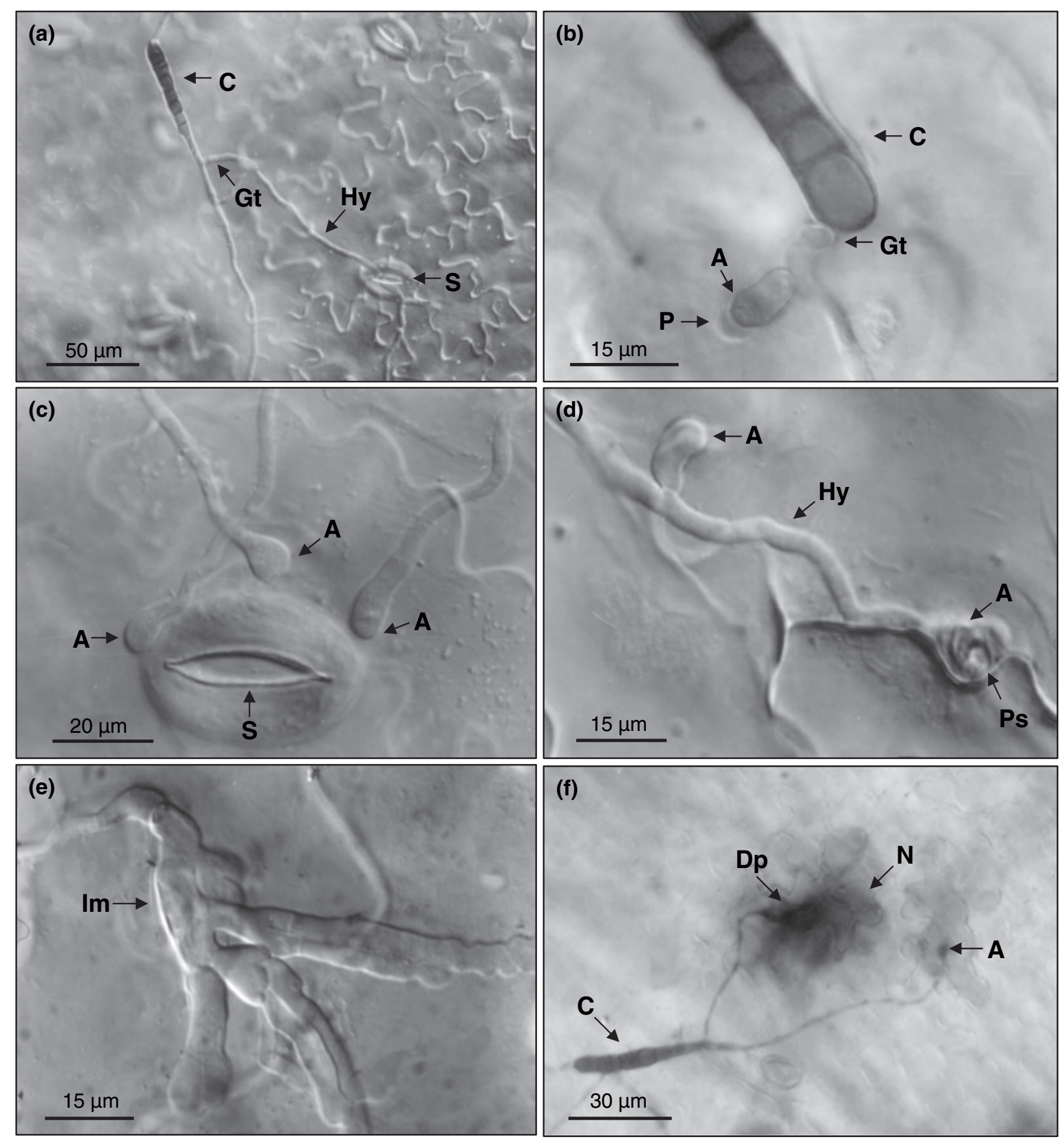

Fig. 1 Light microscopy micrographs of Alternaria solani pre- and post-penetration events in potato cv. Bintje, $24 \mathrm{~h}$ after inoculation. (a) Conidium $(\mathrm{C})$ with two germ tubes $(\mathrm{Gt})$ and a long hypha (Hy) crossing by a stoma (S) with no appressorium formation. (b) Conidium (C) with short germ tube (Gt) with appressorium (A) and semicircular papillae (P) at the attempted penetration site. (c) Three terminal appressoria (A) formed near of stomata (S). (d) Formation of two lateral appressoria (A) by a single hypha (Hy) and direct penteration site (Ps) between cell wall junctions. (e) Host cell penetrated with internal mycelia (Im) larger than the penetration structure. (f) Germinated conidia (C) with appressoria (A) penetrating directly (Dp) in two different sites. Necrosis $(\mathrm{N})$ of the colonized tissue is observed

resistant cultivar Aracy (Table 1). There was a significant association between number of sites with HR and cultivar resistance level when assessing this variable in the middle and upper third sections (Table 1). This event was also influenced by the position of leaves and higher number of sites with HR recorded in the upper than in middle or lower thirds of the plants (Table 2).

\section{Discussion}

As far as we are aware, this is the first histopathological study of the $A$. solani-potato interaction that describes and compares events of the infection process in cultivars with different levels of resistance and its relation with tissue-age. Similarly, to what has been reported in other Alternaria pathosystems, germination of conidia of $A$. solani on potato was neither associ- 

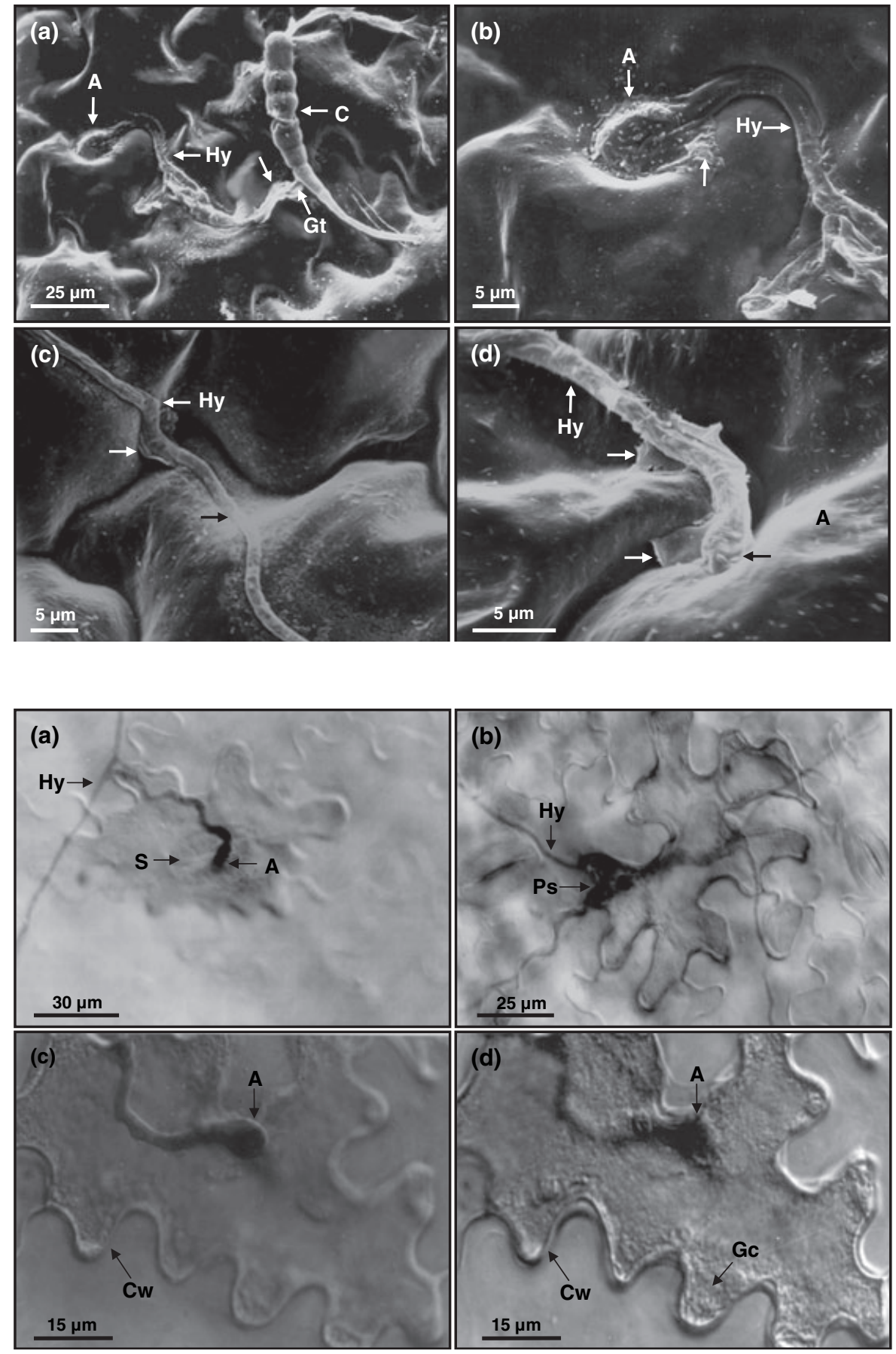

Fig. 2 Scanning electron micrograph of the pre-penetration and penetration structures formed by germinated conidia of Alternaria solani in the susceptible potato cv. Bintje, $24 \mathrm{~h}$ after inoculation. (a) Conidium $(\mathrm{C})$ with germinating tube (Gt), hypha (Hy), and appressorium (A) at the cell wall junctions of the epidermal cells. (b) Detailed view of section (a). (c) Hypha (Hy) adhered in the host surface suggesting the presence of adhesvise extracellular material. (d) Hypha (Hy) with appressorium (A) at initial stage in the cell wall functions of the epidermal cells. Arrows indicate points with substance like extracellular material and apparent adhesion of fungal structure to the host surface ated with cultivar resistance levels (Araújo and Matsuoka, 2004) nor with the tissue-age (Green and Bailey, 2000). However, germination of conidia was slightly lower at all leaf positions in the resistant cultivar (Aracy) suggesting that this event could be affected by host resistance in this pathosystem. Detailed studies properly designed to address this issue should be conducted as inhibition of conidial germination has been already associated with the host resistance to fungal pathogens (Cook, 1980; McLean and Byth, 1981).

Multiple germination tubes growing in any direction over the leaf surface were also observed, in the $A$. solani-Solanum lycopersicum (Araújo and Matsuoka,
2004), A. cirsinoxia-Cirsium arvense, (Green et al., 2001), Alternaria porri-Allium cepa (Aveling et al., 1994) and Alternaria cassiae-Vigna unguiculata (Van den Berg et al., 2003) pathosystems. The fact that only germinated conidia were present on the examined leaf samples could be related to the presence of an extracellular substance observed in the germ tubes, appressorium surface and hypha. According to Gold and Mendgen (1984), in addition to protection of the germ tubes from drought or other stresses, this material might also be involved in the adherence to host surface. Thus, this substance could have facilitated the adhesion of theses structures to the potato leaf surface 
Table 1

Quantification of Alternaria solani infection events in leaves from the lower, middle, and upper plant sections of three potato cultivars, $36 \mathrm{~h}$ after inoculation

Penetration

Cultivar $^{\mathrm{a}} \quad$ Germination $^{\mathrm{b}}$ Appressoria $^{\mathrm{c}}$ Penetrations $^{\mathrm{d}}$ sites with $\mathrm{HR}^{\mathrm{d}}$

\begin{tabular}{lllll}
\hline Lower & & & \\
Aracy (r) & $67.3 \mathrm{ab}^{\mathrm{e}}$ & $0.61 \mathrm{a}$ & $0.66 \mathrm{a}$ & $0.32 \mathrm{a}$ \\
Delta (mr) & $62.0 \mathrm{~b}$ & $0.66 \mathrm{a}$ & $0.62 \mathrm{a}$ & $0.12 \mathrm{~b}$ \\
Bintje (s) & $90.6 \mathrm{a}$ & $0.55 \mathrm{a}$ & $0.80 \mathrm{a}$ & $0.08 \mathrm{~b}$ \\
Middle & & & & \\
Aracy (r) & $71.6 \mathrm{a}^{\mathrm{e}}$ & $0.78 \mathrm{a}$ & $0.83 \mathrm{a}$ & $0.41 \mathrm{a}$ \\
Delta (mr) & $83.3 \mathrm{ab}$ & $0.87 \mathrm{a}$ & $0.76 \mathrm{a}$ & $0.18 \mathrm{~b}$ \\
Bintje (s) & $99.3 \mathrm{~b}$ & $0.72 \mathrm{a}$ & $0.80 \mathrm{a}$ & $0.04 \mathrm{c}$ \\
Upper & & & & \\
Aracy (r) & $57.3 \mathrm{a}$ & $0.54 \mathrm{ab}$ & $0.85 \mathrm{a}$ & $0.58 \mathrm{a}$ \\
Delta (mr) & $61.0 \mathrm{a}$ & $0.81 \mathrm{a}$ & $0.59 \mathrm{a}$ & $0.35 \mathrm{~b}$ \\
Bintje (s) & $88.6 \mathrm{~b}$ & $0.42 \mathrm{~b}$ & $0.76 \mathrm{a}$ & $0.18 \mathrm{c}$
\end{tabular}

${ }^{\mathrm{a}}$ Letters in brackets indicate level of early blight resistance of the cultivars: $\mathrm{r}=$ resistant, $\mathrm{mr}=$ moderately resistant, $\mathrm{s}=$ susceptible.

${ }^{\mathrm{b}}$ Average germination percentage. For each cultivar, the mean value was estimated from seven replicates.

${ }^{\mathrm{c}}$ Average number of appressoria per germinated conidium.

${ }^{\mathrm{d}}$ Proportion of penetration sites with or without HR in relation to the average number of appressoria formed per conidium.

${ }^{\mathrm{e}}$ Values in a column followed by different letters are significantly different at $\alpha=0.05$ according to Fisher LSD test.

Table 2

Effect of leaf position of three potato cultivars on the Alternaria solani infection events, $36 \mathrm{~h}$ after inoculation. For each plant section,

the mean value of each variable was estimated across three cultivars ('Bintje', 'Delta' and 'Aracy') and seven replicates

\begin{tabular}{lcccc}
\hline $\begin{array}{l}\text { Plant } \\
\text { sections }\end{array}$ & Germination $^{\mathrm{a}}$ & Appressoria $^{\mathrm{b}}$ & Penetrations $^{\mathrm{c}}$ & $\begin{array}{c}\text { Penetration } \\
\text { sites with HR }\end{array}$ \\
\hline Upper & $69.0 \mathrm{a}^{\mathrm{d}}$ & $0.58 \mathrm{a}$ & $0.73 \mathrm{a}$ & $0.36 \mathrm{a}$ \\
Middle & $84.5 \mathrm{a}$ & $0.79 \mathrm{a}$ & $0.80 \mathrm{a}$ & $0.21 \mathrm{~b}$ \\
Lower & $73.3 \mathrm{a}$ & $0.60 \mathrm{a}$ & $0.70 \mathrm{a}$ & $0.17 \mathrm{~b}$ \\
\hline
\end{tabular}

${ }^{a}$ Average germination percentage.

${ }^{\mathrm{b}}$ Average number of appressoria per germinated conidium.

${ }^{c}$ Proportion of penetration sites with or without HR in relation to the average number of appressoria formed per conidium.

${ }^{\mathrm{d}}$ Values in a column followed by different letters are significantly different at $\alpha=0.05$ according to Fisher LSD test.

preventing them from being removed during the preparation of the sample. Extracellular substances produced by germinating conidia have already been described in other plant pathogenic fungi (Braun and Howard, 1994; Hau and Rush, 1982; Kuo and Hoch, 1995; Wheeler and Gantz, 1979), including Alternaria species such as $A$. porri (Aveling et al., 1994) and A. cassiae (Mims et al., 1997). However, to date, there was no report of the presence of extracellular substances associated with conidia germlings of A. solani.

Formation of appressoria and penetration occurred predominantly between cell wall junctions at the epidermis and very rarely at the stomata. On this regard, A. solani was similar to $A$. porri (Aveling et al., 1994) and A. cirsinoxia (Green et al., 2001), but different from $A$ lternaria tenuis that penetrates through the stomata to cause leaf spot in beans (Saad and Hagedorn, 1969). Appressoria formation was a necessary step for successful infection of tomato by A. solani. In this pathosystem, there was a clear relationship between low levels of appressoria formation and low number of EB lesions in the resistant tomato genotype CNPH 417 (Araújo and Matsuoka, 2004). However, in some species, such as $A$. cassiae, the pathogen can penetrate the host tissue with or without forming appressoria (Van den Berg et al., 2003). Despite its importance for the infection process, no relationship between appressoria formation and cultivar resistance levels or leaf age was detected in the present study. This result suggested that resistance to EB in these cultivars is not associated with inhibition of appressoria formation.

The host reaction considered here as HR was characterized by high levels of autofluorescence, granular structure of cytoplasm and thickened cell wall. Host responses with similar characteristics were detected in both resistant and susceptible genotypes of potato when challenged with Phytophthora infestans (Ferris, 1955; Freytag et al., 1994; Schröder et al., 1992; Vleeshouwers et al., 2000) and Potato virus $Y$ (Hinrichs-Berger et al., 1999) and in tomato inoculated with A. solani (Araújo and Matsuoka, 2004). In all cases, the response was considered as HR. However, due to the necrotrophic nature of $A$. solani, additional studies are necessary to determine whether the reaction observed in the present study is similar to the HR associated with programmed cell death. Thus, detailed studies with programmed cell death inhibitors, DNA laddering and other techniques are necessary to better characterize this HR response.

The high frequency of HR observed in areas near the stomatal complex may be related to differential accumulation of organ-specific substances involved with plant response to pathogens. Buchter et al. (1997) and Hoegen et al. (2002) observed higher accumulation of pathogenesis-related proteins in areas of the stomatal complex of potato tissues in response to $P$. infestans infection. It is possible that similar events can occur when potato leaves are penetrated by $A$. solani in this area.

Similarly, for germination of conidia and appressoria formation, penetration frequency did not show any relation with the resistance levels of cultivars or with tissue-age. Resistance to EB in these cultivars is likely to be determined by mechanisms acting after pathogen penetration. The capacity of Alternaria to penetrate cells of non-host plants (Brandwagt et al., 2001; McRoberts and Lennard, 1996) supports the hypothesis that major resistance responses may take place after pathogen penetration. One factor that seems to be involved in the post-penetration resistance to EB in potato is the number of penetration sites displaying HR. This event was associated with the resistance levels of cultivars and leaf age. The association between number of penetration sites exhibiting HR with levels of partial resistance has been demonstrated in other pathosystems (Gees and Hohl, 1988; Kowalska and 
Nuiks, 1999; Vleeshouwers et al., 2000). However, as far as we are aware, this is the first report that suggests the possible involvement of HR with quantitative resistance of potato cultivars as well as with the agerelated resistance to $\mathrm{EB}$.

The frequency and/or the timing of HR occurrence might explain the resistance levels of genotypes (Gees and Hohl, 1988; Kowalska and Nuiks, 1999; Vleeshouwers et al., 2000). We have not found differences in the timing of HR occurrence, but it is possible that with shorter sampling intervals, these differences could be detected. On the contrary, HR frequency can contribute to resistance by reducing the number of lesions. Lesions formed in tissues of resistant cultivar and in young leaves had slower expansion rate than those in susceptible cultivars or in old leaves (Dita et al., 2006). Thus, other defense mechanisms that restrict the pathogen growth may contribute to the slower colonization observed in resistant cultivars.

The elicitation of HR by $A$. solani in potato is an interesting issue. Although this defense reaction is more commonly reported in interactions with biotrophic pathogen, HR has been observed in tomato leaves inoculated with $A$. solani (Araújo and Matsuoka, 2004); when challenged with elicitors obtained from the conidia and germlings of this pathogen (Lawrence et al., 2000) or by direct inoculation. Additionally, other species of Alternaria considered as necrotrophic are also able to elicit $\mathrm{HR}$ in their hosts (Brandwagt et al., 2001; Ortega et al., 2005). It seems that HR may also be part of a quantitative defense mechanism that is present in $A$. solani-solanaceous species interactions. Interestingly, Govrin and Levine (2000) showed that hypersensitive cell death did not protect plants against infection by the necrotrophic pathogens Botrytis cinerea and Sclerotium sclerotiorum, but instead, HR seems facilitating colonization of plants. In the $A$. solani-potato interaction the pathogen was apparently restricted to the infection sites in most penetrations sites exhibiting HR. Differences in the strategies employed by the pathogens to overcome host resistance could explain these contrasting observations.

In summary, this study describes the infection process of $A$. solani in potato, comparing cultivars with different level of resistance and tissues with different ages. Data based on the light microscopic observations suggested that HR may be one of the mechanism involved with age-related and genetic resistance to EB in potato. However, further studies are needed in order to characterize this response at the molecular level, and to determine whether the reaction observed in the present study is similar to the HR observed in plantpathogen interactions that follows the gene-to-gene interaction model.

\section{Acknowledgements}

We are grateful to CNPq for financial support and CAPES for M. A. Dita's scholarship. S. H. Brommonshenckel and E. S. G. Mizubuti acknowledge CNPq fellowships.

\section{References}

Allen SJ, Brown JF, Kochman JK. (1983) The infection process, sporulation and survival of Alternaria helianthi on sunflower. Ann App Biol 102:413-419.

Araújo JC, Matsuoka K. (2004) Histopatologia da interação Alternaria solani e tomateiros resistente e suscetível. Fitopatol Bras 129:268-275.

Aveling TAS, Snyman HG, Rijkenberg FHJ. (1994) Morphology of infection of onion leaves by Alternaria porri. Can $J$ Bot 72: 1164-1170.

Brandwagt BF, Kneppers TJA, Van der Weerden GM, Nijkamp HJJ, Hille J. (2001) Most AAL toxin-sensitive Nicotiana species are resistant to the tomato fungal pathogen Alternaria alternata f. sp lycopersici. Mol Plant Microbe Interact 14:460-470.

Braun EJ, Howard RJ. (1994) Adhesion of Cochliobolus heterostrophus conidia and germlings to leaves and artificial surfaces. Exp Mycol 18:211-220.

Buchter R, Stromberg A, Schmelzer E, Kombrink E. (1997) Primary structure and expression of acidic (class II) chitinase in potato. Plant Mol Biol 35:749-761.

Christ BJ. (1991) Effect of disease assessment method on ranking potato cultivars for resistance to early blight. Plant Dis $\mathbf{7 5}$ 353-356.

Cook M. (1980) Peanut wettability and susceptibility to infection to infection to Puccinia arachidis. Phytopathology 70:826-830.

Dita MA, Brommonschenkel SH, Matzuoka K, Mizubuti E. (2006) Components of resistance to early blight in four potato cultivars: effect of leaf position. J Phytopathol 153:1-6.

Douglas DR, Pavek JJ. (1972) Screening potatoes for field resistance to early blight. Am Potato J 49:1-6.

Ferris VR. (1955) Histological study of pathogen-suscept relationships between Phytophthora infestans and derivatives of Solanum demissum. Phytopathology 45:546-552.

Freytag S, Arabatzis N, Hahlbrock K, Schmelzer E. (1994) Reversible cytoplasmic rearrangements precede wall apposition, hypersensitive cell-death and defense-related gene activation In potato Phytophthora infestans interactions. Planta 194:123-135.

Gees R, Hohl HR. (1988) Cytological comparison of specific (R3) and general resistance to late blight in potato leaf tissue. Phytopathology 78:350-357.

Gold RE, Mendgen K. (1984) Cytology of basidiospore germination, penetration, and early colonization of Phaseolus vulgaris by uromyces appendiculatus var appendiculatus. Can J Bot 62:19892002.

Govrin EM, Levine A. (2000) The hypersensitive response facilitates plant infection by the necrotrophic pathogen Botrytis cinerea. Curr Biol 10:751-757.

Green S, Bailey KL. (2000) Effects of leaf maturity, infection site, and application rate of Alternaria cirsinoxia conidia on infection of Canada thistle (Cirsium arvense). Biol Control 19:167-174.

Green S, Bailey KL, Tewari JP. (2001) The infection process of Alternaria cirsinoxia on Canada thistle (Cirsium arvense) and host structural defence responses. Mycol Res 105:344-351.

Hau FC, Rush MC. (1982) Preinfectional interactions between $\mathrm{Hel}$ minthosporium oryzae and resistant and susceptible rice plants. Phytopathology 72:285-292.

Hinrichs-Berger J, Harfold M, Berger S, Buchenauer H. (1999) Cytological responses of susceptible and extremely resistant potato plants to inoculation with potato virus Y. Physiol Mol Plant Pathol 55:143-150.

Hoegen E, Stromberg A, Pihlgren U, Kombrink E. (2002) Primary structure and tissue-specific expression of the pathogenesis-related protein PR-1b in potato. Mol Plant Pathol 3:329-345.

Kowalska A, Nuiks RE. (1999) Histology of quantitative resistance in flax to flax rust fungus (Melampsora lini). Can J Plant Pathol 21:354-360.

Kuo KC, Hoch HC. (1995) Visualization of the extracellular matrix surrounding pycnidiospores, germlings, and appressoria of Phyllosticta ampelicida. Mycologia 87:759-771.

Lawrence CB, Singh NP, Qiu JS, Gardner RG, Tuzun S. (2000) Constitutive hydrolytic enzymes are associated with polygenic 
resistance of tomato to Alternaria solani and may function as an elicitor release mechanism. Physiol Mol Plant Pathol 57:211-220.

McLean RJ, Byth DE. (1981) Histological studies of the pre-penetration development and penetration of soybeans by rust, Phakopsora pachyrhizi Syd. Aust J Agric Res 32:435-443.

McRoberts N, Lennard JH. (1996) Pathogen behaviour and plant cell reactions in interactions between Alternaria species and leaves of host and nonhost plants. Plant Pathol 45:742-752.

Mims CW, Rogers MA, VanDyke CG. (1997) Ultrastructure of conidia and conidium germination in the plant pathogenic fungus Alternaria cassiae. Can J Bot 75:252-260.

Ortega X, Velasquez JC, Perez LM. (2005) IP3 production in the hypersensitive response of lemon seedlings against Alternaria alternata involves active protein tyrosine kinases but not a G-protein. Biol Res 38:89-99.

Pelletier JR, Fry WE. (1989) Characterization of resistance to early blight in 3 potato cultivars: incubation period, lesion expansion rate, and spore production. Phytopathology 79:511-517.

Reifschneider FJB, Furumoto O, Filgueira FAR. (1984) Illustrated key for the evaluation of early blight of potatoes. Plant Prot Bull 32:91-94.

Rotem J. The Genus Alternaria: Biology, Epidemiology and Pathogenicity. St Paul, Minnesota, APS Press, 1994.

Saad S, Hagedorn DJ. (1969) Host-parasite relations in initiation and development of bean Alternaria leaf spot. Phytopathology 59:1773.
Schröder M, Hahlbrock K, Kombrink E. (1992) Temporal and spatial patterns of 1,3-beta-glucanase and chitinase induction in potato leaves infected by Phytophthora infestans. Plant J 2:161-172.

Sillero JC, Rubiales D. (2002) Histological characterization of resistance to Uromyces viciae- fabae in faba bean. Phytopathology 92:294-299.

Van den Berg N, Aveling TAS, Venter SL. (2003) Infection studies of Alternaria cassiae on cowpea. Australas Plant Pathol 32:33-38.

Van der Waals JE, Korsten L, Aveling TAS, Denner FDN. (2003) Influence of environmental factors on field concentrations of Alternaria solani conidia above a South African potato crop. Phytoparasitica 31:353-364.

Vandyke CG, Trigiano RN. (1987) Light and scanning electronmicroscopy of the interaction of the biocontrol fungus Alternaria cassiae with sicklepod (Cassia obtusifolia). Can J Plant Pathol 9:230-235.

Vleeshouwers V, van Dooijeweert W, Govers F, Kamoun S, Colon LT. (2000) The hypersensitive response is associated with host and nonhost resistance to Phytophthora infestans. Planta 210:853-864.

Wheeler H, Gantz D. (1979) Extracellular sheaths on hyphae of 2 species of Helminthosporium. Mycologia 71:1127-1135.

Xi K, Burnett PA, Tewari JP, Chen MH, Turkington TK, Helm JH. (2000) Histopathological study of barley cultivars resistant and susceptible to Rhynchosporium secalis. Phytopathology 90:94-102. 